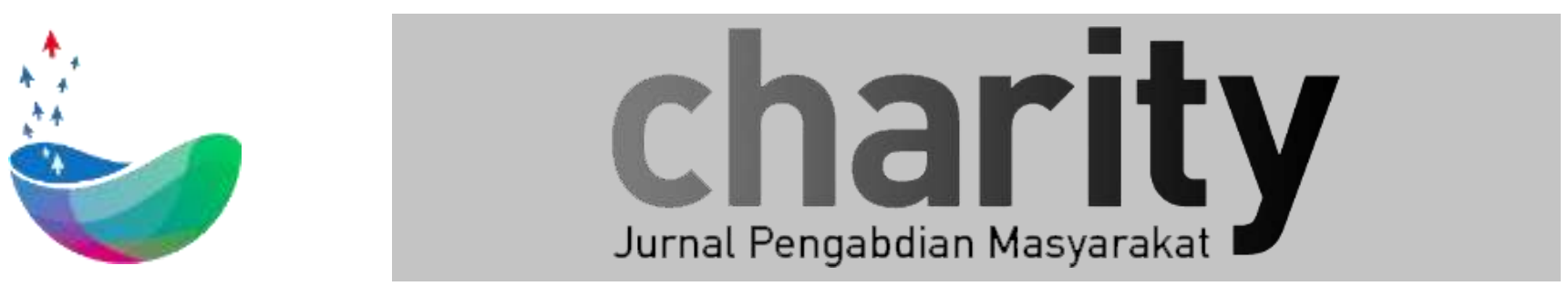

\title{
KEGIATAN STUDI PENGUATAN LEMBAGA KOPERASI PADA MASYARAKAT PETANI GARAM DI KAWASAN PESISIR PANTAI
}

\author{
${ }^{1}$ Fakultas Ekonomi Bisnis, Universitas Telkom \\ ${ }^{2}$ Fakultas Ekonomi Bisnis, Universitas Telkom \\ ${ }^{3}$ Fakultas Ekonomi Bisnis, Universitas Telkom \\ ${ }^{4}$ Fakultas Ekonomi Bisnis, Universitas Telkom \\ ${ }^{5}$ Fakultas Ekonomi Bisnis, Universitas Telkom \\ *etikusmiati@vahoo.co.id
}

Eti Kusmiati ${ }^{1}$, Hernawaty ${ }^{2}$, Shelfi Malinda ${ }^{3}$, Yusriana $^{4}$

\section{INFO ARTIKEL}

Diterima 1 November 2017

Direvisi 7 November 2017

Disetujui 16 November 2017

Tersedia Online 24 Oktober 2018

\begin{abstract}
ABSTRAK
Pembangunan ekonomi sebagai suatu upaya untuk mengembangkan kegiatan ekonomi dan taraf kehidupan masyarakat merupakan suatu upaya yang sangat kompleks, karena banyak faktor yang mempengaruhinya. Upaya melakukan pembangunan ekonomi dengan mengoptimalkan keikutsertaan peran masyarakat dalam pembangunan ekonomi dan memberi penguatan terhadap lembaga-lembaga ekonomi yang ada di masyarakat merupakan suatu pemikiran penting dalam pemberdayaan masyarakat (empowerment).

Dalam rangka mensupport Program tersebut maka dibutuhkan Penataan Kelembagaan dan Ketatalaksanaan serta pengorganisasian yang baik hubungan antara petani garam dengan pelaku industri terkait dengan tataniaga produksi garam agar petani garam mempunyai posisi tawar maka dibutuhkan skenario kelembagaan yang baik serta pengorganisasian kumpulan petani garam tersebut. Untuk itu Studi Penguatan Lembaga Koperasi Masyarakat Petani Garam di Kabupaten Sampang, Pamekasan dan Bangkalan ini, yang dilaksanakan oleh Kementerian Pembangunan Daerah Tertinggal yang tentunya diharapkan juga peran sektor-sektor terkait, maupun oleh Pemerintah Daerah, sehingga kegiatan tersebut tepat sasaran dan dapat mencapai hasil yang optimal, dalam rangka meningkatkan kinerja dan produktiftas di daerah tertinggal.
\end{abstract}

Keyword : Garam, Petani

\author{
Korespondensi : \\ Direktorat Penelitian dan Pengabdian Masyarakat, Universitas Telkom \\ Jl. Telekomunikasi No. 1, Terusan Buah Batu, Bandung, 40257 \\ Indonesia. \\ E-mail: charity@telkomuniversity.ac.id \\ ORCID ID: \\ Penulis Pertama: - \\ https://doi.org/10.25124/charity.v1i01.1585 \\ Paper_reg_numberCharity0013010113 @ The Authors. Published by Directorate of Research and Community \\ Service, Telkom University. \\ This is an open access article under the CC BY-NC 4.0 license (https://creativecommons.org/licenses/by-nc/4.0/)
}




\section{PENDAHULUAN}

\subsection{Latar Belakang}

Pembangunan ekonomi sebagai suatu upaya untuk mengembangkan kegiatan ekonomi dan taraf kehidupan masyarakat merupakan suatu upaya yang sangat kompleks, karena banyak faktor yang mempengaruhinya. Upaya melakukan pembangunan ekonomi dengan mengoptimalkan keikutsertaan peran masyarakat dalam pembangunan ekonomi dan memberi penguatan terhadap lembaga-lembaga ekonomi yang ada di masyarakat merupakan suatu pemikiran penting dalam pemberdayaan masyarakat (empowerment).

Salah satu agenda pembangunan Kabinet Indonesia Bersatu (KIB) II adalah peningkatan kesejahteraan rakyat di samping agenda lainnya yaitu mewujudkan Indonesia yang damai, adil dan demokratis dengan melibatkan peran serta/partisipasi dari masyarakat. Peningkatan kesejahteraan rakyat merupakan salah satu prioritas dalam konteks pembangunan saat ini.Hal ini merupakan indikasi bahwa tingkat kesejahteraan rakyat Indonesia relatif masih rendah terutama di daerah tertinggal, terpencil dan daerah perbatasan. Fenomena ini terjadi akibat adanya ketimpangan atau tidak meratanya pelaksanaan pembangunan selama ini karena berbagai faktor. Pada hakikatnya semua aspek pembangunan berorientasi pada peningkatan kesejahteraan masyarakat melalui pembangunan fisik dan non fisik (termasuk di dalamnya pembangunan manusia Indonesia seutuhnya, SDM, pranata sosial dan kelembagaan).

Dalam beberapa tahun belakangan ini pemerintah pusat maupun pemerintah daerah telah berupaya melaksanakan berbagai program pembangunan dengan paradigma baru dengan meninggalkan pola pembangunan yang bersifat top-down yang ternyata kurang efektif dalam pembinaan komunitas lokal di samping adanya

aturan-aturan yang sentralistik dan tidak relevan dengan kebutuhan masyarakat. Melalui paradigma baru ini, masyarakat diharapkan dapat bertindak dan berperan sebagai subjek pembangunan dan tidak lagi sebagai objek pembangunan, dengan demikian partisipasi masyarakat baik dalam bentuk kelompok/lembaga maupun individu sangat diharapkan, seiring dengan meningkatnya peran dan fungsi lembaga sosial ekonomifkelompok masyarakat sebagai wadah organisasi dan motor penggerak dalam masyarakat di daerah/perdesaan. Selain itu juga lembaga- lembaga masyarakat yang ada dapat dijadikan mitra kerja pemerintah dalam proses pembangunan.

Perencanaan pembangunan berasal dari lembaga/kelompok masyarakat itu sendiri sangat membantu keberhasilan karena umumnya masyarakat lebih banyak tahu tentang kebutuhannya dan permasalahan yang dihadapi, dengan demikian pelibatan masyarakat dalam proses pembangunan baik secara kelompok/lembaga maupun perorangan merupakan kebijakan yang tepat dan sesuai, serta membantu dalam keberhasilan pembangunan, sehingga hasilnya sesuai dengan kebutuhan dan keinginan, serta dapat dirasakan manfaatnya oleh masyarakat.

Untuk mencapai kesejahteraan masyarakat tersebut, pemerintah melalui Kementerian Pembangunan Daerah Tertinggal yang dibentuk dalam Kabinet Indonesia Bersatu II telah menetapkan langkah-langkah pencapaian sasaran tersebut melalui kegiatan sebagai berikut : (a) Pengembangan ekonomi lokal, (b) Pemberdayaan masyarakat, (c) Pengurangan keterisolasian daerah, (d) Pengembangan kelembagaan, dan (e) penanganan karakteristik khusus daerah yang dikemas dalam suatu bentuk Strategi Nasional (Stranas) Kementerian Pembangunan Daerah Tertinggal. Berkenaan dengan itu, untuk memberdayakan masyarakat secara optimal dalam mempercepat proses pembangunan di daerah tertinggal, maka perlu dilakukan suatu kegiatan yang berhubungan dengan industri garam di Kabupaten Sampang, Pamekasan dan Bangkalan. Selama ini untuk memenuhi keperluan garam baik untuk konsumsi maupun untuk keperluan industri, sangat tergantung hanya pada garam impor. Ke depan diharapkan 
pemenuhan garam untuk konsumsi dan industri dapat dipenuhi dari produksi dalam negeri yang dilakukan di Pulau Madura yang dikenal sebagai pulau penghasil garam, sehingga akan terjadi penghematan devisa yang akan berdampak terhadap peningkatan pembangunan di daerah tertinggal.

Berdasarkan catatan dari Kementerian Perindustrian, dalam satu tahun Indonesia membutuhkan garam kurang lebih 2,5 juta ton (rumah tangga dan industri pangan 1,0 juta ton, perminyakan 100000 ton, industri tekstil dan kulit 98000 ton industri CAP 1,2 juta ton dan industri farmasi 100 ton), dan sekitan 1,6 juta ton garam harus diimpor untuk memenuhi kebutuhan tersebut. Berkaitan dengan hal tersebut pada tahun 2010 pemerintah telah mencanangkan swasembada garam nasional melalui produksi dalam negeri. Swasembada garam nasional dilakukan dengan pendekatan :

- Pemenuhan kebutuhan garam konsumsi (kelompok Non CAP) yaitu garam untuk keperluan konsumsi rumah tangga dan sejenisnya termasuk garam di luar kebutuhan industri Chlor Alkali Plant (CAP) seperti garam untuk pengasinan ikan, industri makanan, industri pakan ternak, industri pengeboran minyak, industri penyamakan kulit dan industri tekstil.

- Pemenuhan kebutuhan garam untuk industri CAP termasuk industri pharmaceutical.

Provinsi Jawa Timur, khususnya di Kabupaten Sampang, Pamekasan dan Bangkalan sebagai lahan dan industri garam selayaknya mendapat perhatian atau keberpihakan dari pemerintah. Industri garam rnerupakan upaya sadar dan terencana dalam rangka mengelola dan memanfaatkan sumberdaya guna mencapai tujuan pembangunan, yakni meningkatkan kualitas kehidupan masyarakat dan bangsa. Perkembangan industri garam memang membawa akibat- akibat positif bagi kehidupan manusia. Hakikat perkembangan industri garam ini, akan selalu berarti bagi perkembangan peradaban manusia dan lebih konkrit bagi perkembangan industri pada khususnya akan selalu berarti pula bagi peningkatan kesejahteraan masyarakat. Keadaan alam yang dikelilingi lautan, masyarakat

modern dituntut untuk mengelola SDA yang ada, seperti yang kita ketahui bahwa Pulau Madura tidak hanya terkenal dengan budaya carok, karapan sapi dan jamu Madura saja akan tetapi juga dikenal sebagai penghasil garam, di antaranya di Kabupaten Sampang, Pemekasan dan Bangkalan.

Kabupaten Sampang, Pamekasan dan Sumenep merupakan areal yang merupakan bagian dari Roadmap Program Swasembada Garam Nasional, dimana mulai tahun 2010 telah ada aktifitas identifikasi dan konsolidasi, serta merupakan areal yang menjadi sasaran untuk program ekstensifikasi, intensifikasi, revitalisasi, peningkatan mutu garam rakyat, peningkatan jumlah dan mutu garam konsumsi beryodium, serta program pemberdayaan masyarakat petani garam (pengembangan desa garam, kebijakan tata niaga garam dan pengembangan kelembagaan). Dengan program ini diharapkan pada tahun 2015 Swasembada garam industri dapat terealisasi.

Berdasarkan uraian diatas maka dapat disimpulkan bahwa permasalahan yang melatarbelakangi perlunya menyelenggarakan kegiatan "Studi Penguatan Lembaga Koperasi Masyarakat Petani Garam di Kabupaten Sampang, Pamekasan dan Bangkalan" yang diharapkan dapat memberikan rumusan kebijakan untuk meningkatkan peran petani garam.

Dalam rangka mensupport Program tersebut maka dibutuhkan Penataan Kelembagaan dan Ketatalaksanaan serta pengorganisasian yang baik hubungan antara petani garam dengan pelaku industri terkait dengan tataniaga produksi garam agar petani garam mempunyai posisi tawar maka dibutuhkan skenario kelembagaan yang baik serta pengorganisasian kumpulan petani garam tersebut. Untuk itu Studi Penguatan Lembaga Koperasi Masyarakat Petani Garam di Kabupaten Sampang, Pamekasan dan Bangkalan ini, yang dilaksanakan oleh Kementerian Pembangunan Daerah Tertinggal yang tentunya diharapkan juga peran sektorsektor terkait, maupun oleh Pemerintah Daerah, sehingga kegiatan tersebut tepat sasaran dan 
dapat mencapai hasil yang optimal, dalam rangka meningkatkan kinerja dan produktiftas di daerah tertinggal.

\subsection{Maksud}

Kegiatan ini dimaksudkan meningkatkan penguatan kelembagaan koperasi petani garam di daerah tertinggal khususnya di daerah pesisir pantai.

\subsection{Tujuan}

Tujuan studi penguatan lembaga koperasi masyarakat petani garam adalah:

a. Merumuskan kebijakan-kebijakan tentang penguatan kelembagaan yang dapat dijadikan acuan dalam pengambilan keputusan terhadap kelembagaan koperasi petani, khususnya petani garam di daerah tertinggal.

b. Menguatkan lembaga-lembaga koperasi, khususnya petani garam sehingga dapat meningkatkan peran serta/pertisipasi masyarakat.

c. Mengembangkan sinergitas program/kegiatan dalam upaya peninkatan kapasitas kelembagaan koperasi masyarakat petani garam.

\subsection{Sasaran}

Adapun sasaran dari kegiatan ini adalah:

a. Tersedianya rumusan kebijakan -kebijakan tentang penguatan kelembagaan yang dapat dijadikan acuan dalam pengambilan keputusan terhadap koperasi petani khususnya petani garam di daerah tertinggal.

b. Terlaksananya penguatan lembaga-lembaga koperasi khususnya petani garam sehingga dapat meningkatkan peran serta/partsipasi masyarakat perdesaan dalam pemberdayaan ekonomi local.

c. Terlaksananya sinergitas program/kegiatan dalam upaya peningkatan kapasitas kelembagaan koperasi masyarakat petani garam. 


\subsection{Keluaran (Output)}

Indikator Keluaran yang diharapkan dari kegiatan ini yaitu :

a. Tersedianya satu hasil kajian mengenai penguatan lembaga koperasi petani garam di tiga kabupaten dalam rangka peningkatan potensi lembaga masyarakat daerah tertinggal untuk menuju kemandirian masyarakat.

b. Terususunnya rumusan kebijakan tentang penguatan kelembagaan koperasi di daerah tertinggal.

\subsection{Lokasi Pelaksanaan}

Kegiatan di laksanakan di tiga wilayah, yaitu Kabupaten Sampang, Kabupaten Pamekasan dan Kabupaten Bangkalan.

\subsection{Ruang Lingkup Kegiatan}

Guna mencapai tujuan, sasaran dan output studi yang dilakukan, maka ruang lingkup kajian yang dirumuskan adalah mengumpulkan, mengklasifikasikan dan menganalisis data dan informasi yang relevan dengan kajian studi, yaitu:

1. Identifikasi kebijakan-kebijakan pengembangan kelembagaan koperasi petani garam

2. Identifikasi kelembagaan koperasi di daerah tertinggal tempat kajian

3. Identifikasi potensi dan masalah usaha petani garam

4. Identifikasi peluang dan ancaman pengembangan usaha dan kelambagaannya

5. Analisis pengembangan usaha dan peran kelembagaan koperasi petani garam

6. Workshop tentang pengelolaan dan pengembangan kelembagaan koperasi petani garam

7. Rumusan kebijakan pengembangan kelembagaan koperasi petani garam

8. Pelaporan hasil kajian

Dari delapan ruang Lingkup kegiatan diatas pada hakekatnya dapat dikelompokkan pada kegiatan identifikasi, pengkajian, analisa dan pelaporan hasil kajian Penguatan Lembaga Koperasi Masyarakat Petani Garam di Kabupaten Sampang, Pamekasan dan Bangkalan 


\section{LANDASAN TEORITIS}

\subsection{Konsep Pembangunan}

Salah satu konsep atau teori yang sering digunakan dalam pembangunan adalah "GNP-trickle down effect model". Model ini menekankan pentingnya mengupayakan pertumbuhan GNP (Gross National Product) yang setinggi- tingginya dalam pembangunan, yang hasilnya kemudian diharapkan akan menetes ke bawah, ke seluruh masyarakat. Model ini juga mengasumsikan bahwa masalah keterbelakangan (underdevelopment) negara-negara ketiga (berkembang) adalah masalah "inherent deficiencies : economic, social, and cultural...To confront its problem, therefore, the Third World needed to "catch up" to technologically - advanced countries, through inputs of capital and technology and through adopting" modern"values" (Kindervatter, 1979: 18).

Konsep pembangunan di atas dianggap sudah usang dan mendapat tantangan dari para pemikir pembaruan. Para pemikir pembaruan melihat keterbelakangan bukanlah masalah "inherent deficiencies" sebagaimana dikemukakan konsep lama atau tradisional di atas, melainkan terkait dengan sejarah "unequal power relationships between the Third World and technologically advanced countries, from the era colonialism to the present" (Kindervatter, 1979:18). Oleh karena itu dilihat dari analisis historis, yang diperlukan untuk memecahkan masalah keterbelakangan negara-negara berkembang adalah : pertama, memecahkan kesulitan internal ekonomi dan kedua, mengubah hubungan eksternal dengan negara yang maju secara teknologi.

Hubungan yang tidak seimbang antara negara berkembang dan maju sebagai akibat kolonialisme itu, adalah bentuk dependensi, dan karenanya disebut teori dependensi. Berdasarkan teori ini situasi ekonomi suatu bangsa adalah hasil dari perkembangan dan ekspansi ekonomi yang menjajahnya (Dos Santos, 1973). Mereka yang menganut teori ini meyakini bahwa ketidakseimbangan hubungan perdagangan internasional dan investasi itu hanyalah menguntungkan negara yang secara teknologi maju dan sebaliknya merugikan negara sedang berkembang.

Adapun strategi untuk mengatasi depedensi itu menurut Baran (1973 : 93) yang dikutip Kindervatter adalah: 'For backward countries to enter the road of economic growth and social progress, the political framework of their existence has to be drastically revamped. The alliance between feudal landlord, industrial royalist, and capitalist middle classes has to be broken'. Sementara itu, Szentes (1976 : 228) mengemukakan: "Where the mechanism of exploitation is a spontaneous mechanism built on the internal structure of the exploited countries on the one hand, and is part and consequence of the whole mechanism of the world economy itself on the other, the internal solution can only be structural, consequently also political one, and the international solution only a political, consequently a structural one".

Ahli lain yang mengritik konsep pembangunan lama adalah Goulet (1975).Menurut pandangannya teori pembangunan ekonomi yang ada itu anti pembangunan "because of their absolutization of the means, emphasis on materialism, and ignoring of the qualitative aspects of life". Menurutnya kebanyakan teori pembangunan menegasikan "the real issue of development: human values choices, how those choices are made and by whom..." Oleh karena itu ia menegaskan bahwa "...for developed and underdeveloped societies alike, basic questions are neither economical, political nor technical, but moral".

Akhirnya, pada tahun 1975, Dag Hammarkjold Foundation di Swedia menyusun formula baru mengenai konsep pembangunan untuk negara berkembang. Konsep ini memiliki 5 ciri umum, yaitu: need oriented, endogenous, self-reliant, ecologically sound, and based on the transformation of social structure (Kindervatter, 1979:45). Hal tersebut sampai saat ini masih tetap sangat relevan, dan masih belum berhasil dilaksanakan oleh sebagian besar Negara-negara sedang berkembang.

Need oriented, maksudnya pembangunan harus sesuai dan memenuhi kebutuhan manusia, baik material maupun nonmaterial, dimulai dari pemenuhan kebutuhan dasar dari orang-orang yang diekploitasi dan dikuasai, yang merupakan bagian terbesar penduduk dunia, dan menjamin pada saat yang sama upaya memanusiakan manusia dengan memenuhi kebutuhan mereka untuk berekspresi, berkreasi, diperlakukan adil, memahami dan menentukan nasibnya sendiri. 
Endogenous, artinya pembangunan berasal dari "hati" setiap masyarakat, yang menentukan nilainilai dan visi masa depan mereka sendiri. Oleh karena pembangunan bukanlah proses linier, tidak ada model pembangunan universal, yang berlaku untuk setiap masyarakat, dan karenanya hanya ada model pembangunan yang khas yang akan menjawab tiap-tiap situasi masyarakat yang khas pula.

Self Reliant, maksudnya setiap masyarakat seharusnya mampu mengandalkan kekuatannya sendiri, menggunakan sumber alam dan enerji serta lingkungan budayanya sendiri. Mengandalkan kemampuan sendiri seyogyanya dilaksanakan baik di tingkat nasional maupun internasional (self reliant kolektif), namun tetap berakar di tingkat sistem setiap masyarakat.

Ecologically sound, maksudnya pembangunan hendaknya menggunakan secara rasional sumbersumber biosfir, dengan kesadaran penuh mengenai keselamatan ekosistem baik local, rejional, nasional maupun global dengan mempertimbangkan kepentingan sekarang dan generasi mendatang. Pembangunan seharusnya membuat semua orang memiliki akses yang sama terhadap sumber- sumber dan memperlakukannya secara hati-hati dan menggunakan teknologi yang secara sistem relevan.

Based on structural transformation, maksudnya bahwa pembangunan dibutuhkan, lebih sering daripada tidak, dalam kaitan dengan sistem kegiatan ekonomi dan dalam distribusi spasial untuk merealisasikan kondisi kemampuan mengelola sendiri dan partisipasi dalam pengambilan keputusan oleh semua yang akan terkena pengaruh, mulai dari masyarakat desa atau kota sampai masyarakat dunia secara keseluruhan, yang tanpa hal tersebut tujuan-tujuan pembangunan di atas tidak akan tercapai.

Selanjutnya perlu diperjelas berkaitan dengan target pembangunan, bahwa The UN Strategy for the Second Development Decade, tidak hanya memasukan "the traditional economic targets for GNP and per capita growth, but also goals related to employment, education, health, nutrition, housing, and social welfare" (Donal, 1971).

Kemudian secara lebih khsusus perlu dikembangkan pula pemahaman mengenai pembangunan masyarakat atau Community Developmen (CD). Dalam hal ini, CD didefinisikan sebagai “... a planned effort to produce assets that increase the capacity of residents to improve their quality of life. These assets may include general forms of community capital: physical, human, social, financial and environmental" (Gary Paul Green \& Anna Haines, 2002:VII).

Pembangunan masyarakat adalah usaha terencana untuk menghasilkan aset (kekayaan) yang akan meningkatkan kapasitas penduduk (masyarakat) untuk memperbaiki kualitas hidup mereka. Kekayaan yang dimaksud termasuk sejumlah modal masyarakat, seperti : modal fisik, manusia, sosial, keuangan dan lingkungan. Secara visual, hal ini bisa digambarkan sbb. 


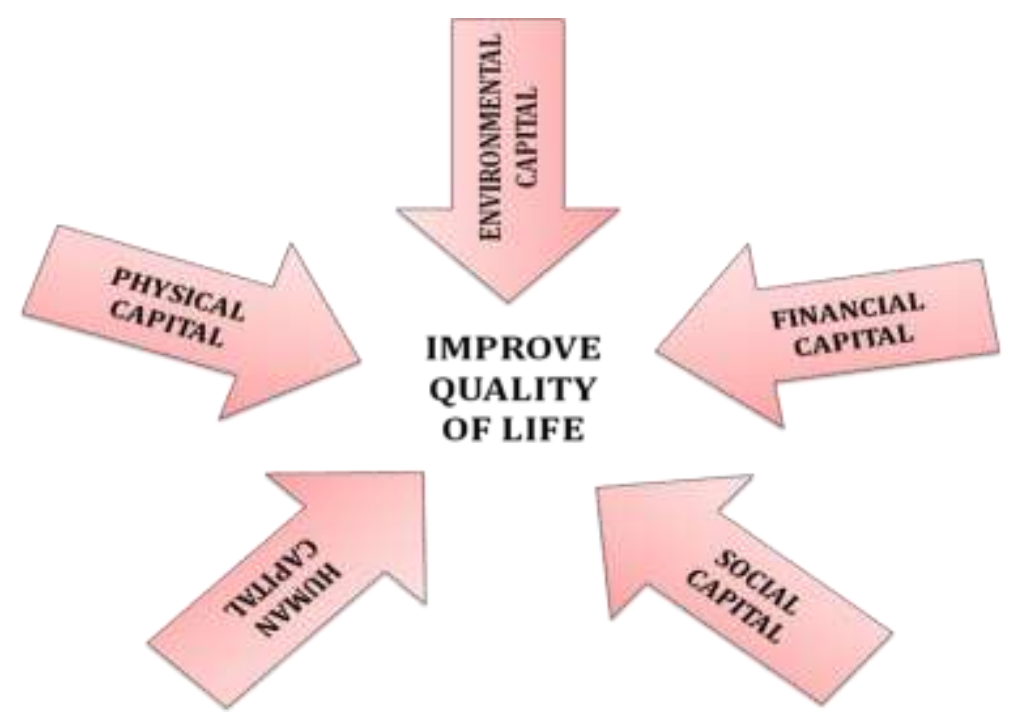

Gambar 2.1. Modal Masyarakat untuk Meningkatkan Kualitas Hidup

Sementara itu menurut Todaro, ada tiga core values pembangunan, seperti digambarkan sebagai berikut :

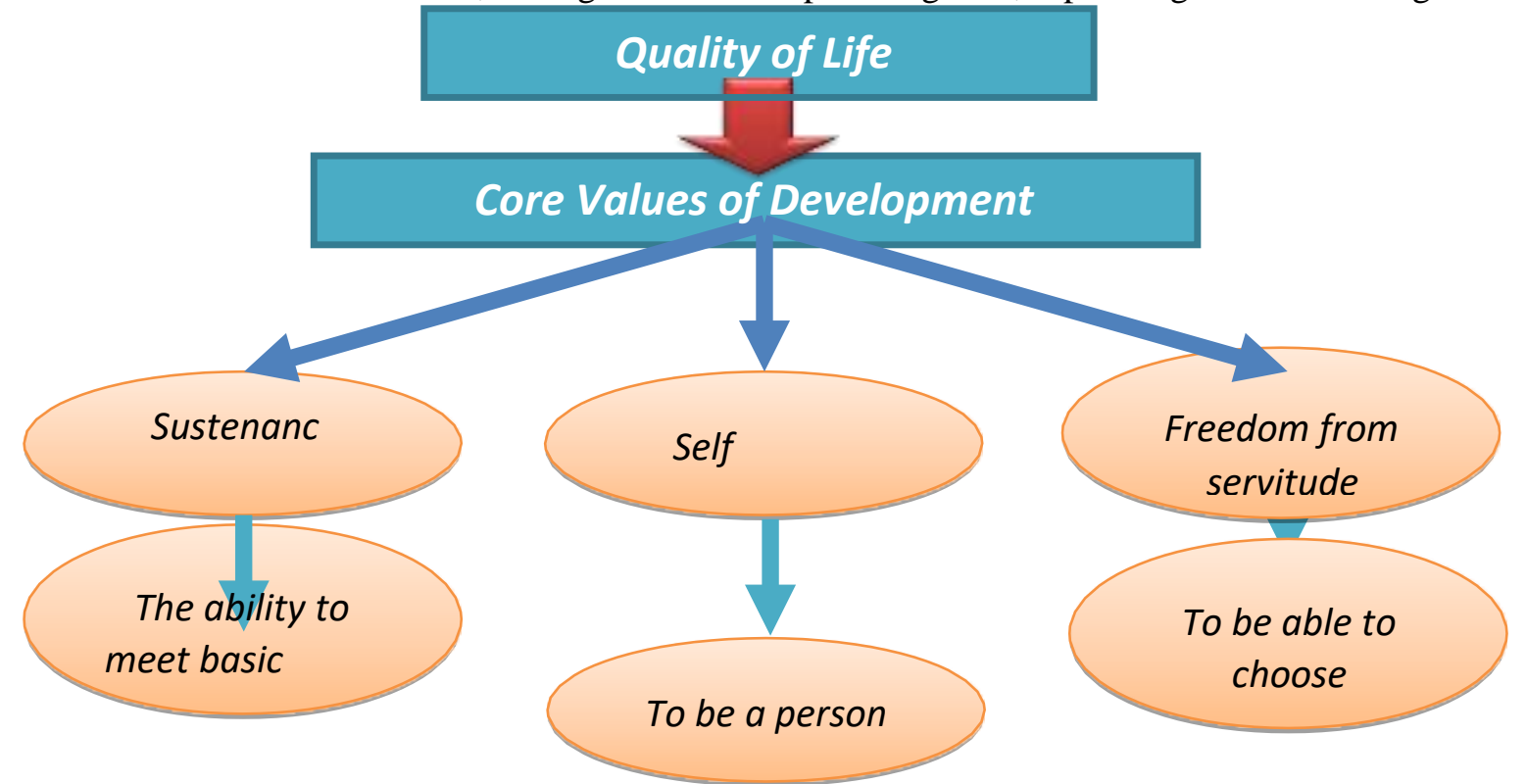

Gambar 2.2. Tiga Nilai Inti Pembangunan Sumber : Todaro (2003)

Gambar di atas mengandung makna bahwa pembangunan harus mampu menyediakan makan, atau kebutuhan dasar. Pembangunan juga harus memberi 
ruang untuk penghargaan diri sebagai seorang manusia dan harus mampu membebaskan dari perbudakan, sehingga manusia bebas memilih.

Dari ketiga values tersebut kemudian diturunkan tiga tujuan pembangunan seperti digambarkan sebagai berikut:

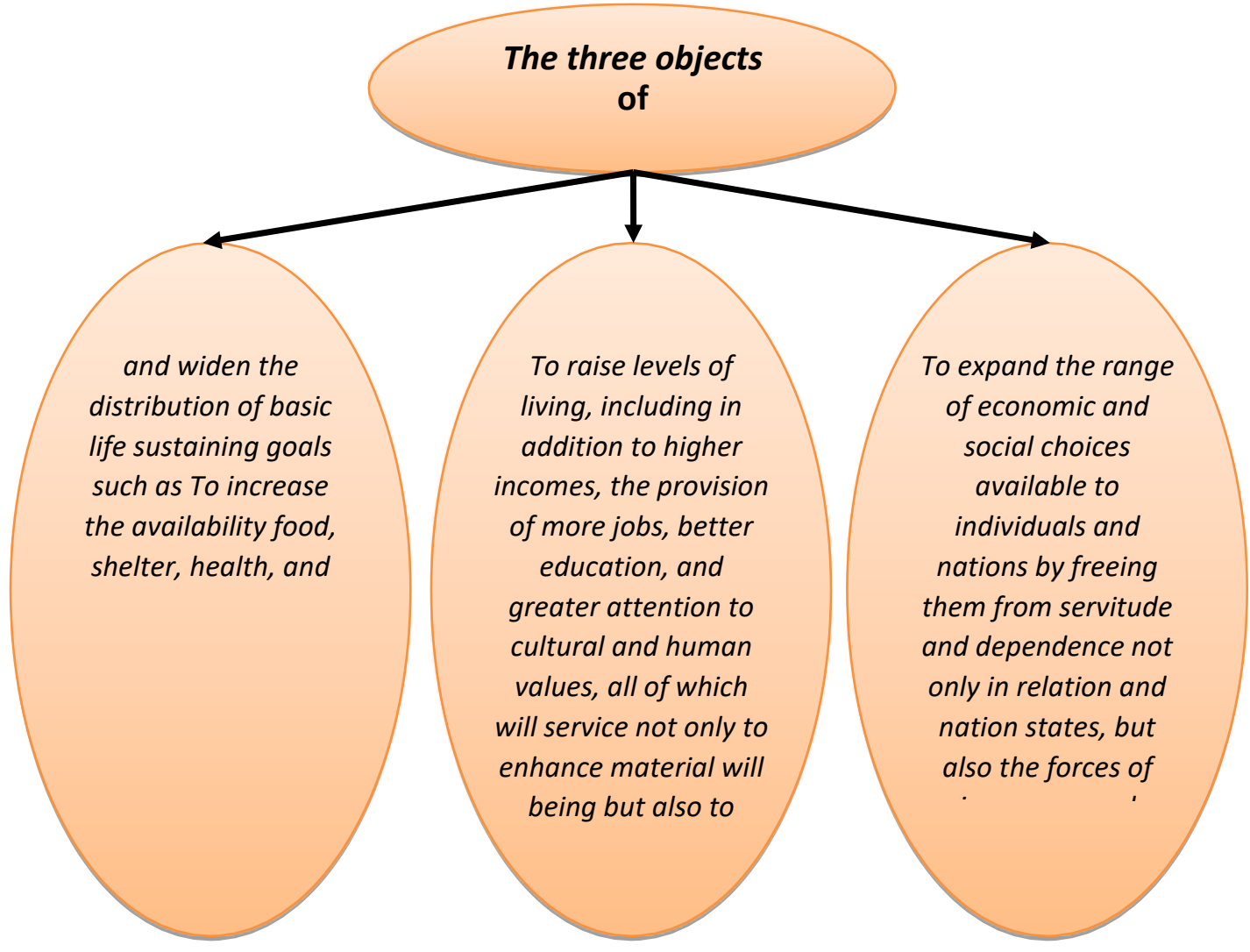

Gambar 2.3. Tiga Tujuan Pembangunan Sumber : Todaro (2003)

Gambar 2.3. di atas menegaskan bahwa pembangunan harus bertujuan meningkatkan ketersediaan dan perluasan distribusi kebutuhan pokok seperti makanan, perumahan, keselamatan dan perlindungan. Pembangunan juga bertujuan meningkatkan taraf kehidupan termasuk memperoleh pendapatan yang lebih tinggi, penyediaan lebih banyak pekerjaan, pendidikan yang lebih baik, dan perhatian lebih terhadap nilai budaya dan kemanusiaan, yang kesemua itu diperlukan tidak hanya untuk meningkatkan kesejahteraan material tetapi juga kepentingan spiritual individu yang lebih baik.

Terkait dengan pendidikan dalam hal ini perlu ditekankan bahwa peran pendidikan di dalam perubahan sistem, secara tradisional umumnya tidak banyak atau kecil saja. Pendidikan formal, misalnya, cenderung mendukung status quo dan memelihara nilai-nilai sosio sistem, norma, mitos, yang sudah ada. Oleh karena itu, banyak ahli sejak tahun 60-an yang mulai berpaling ke pendidikan nonformal, yang tidak terlalu terikat secara tradisional dan memiliki peluang untuk memberikan kontribusi terhadap perubahan sistem, termasuk sistem sosial. Dalam hal ini, Social change, therefore, implies not only an alteration in man's behavior and in the relationship between that behavior and respective human and physical environment, but also requires an alteration in societal rules and structures enabling the new behavior and relationship to establish (Labelle, 1976; dalam Kindervatter, 1979 : 51).

Kebutuhan akan pendidikan nonformal dilandasi oleh kebutuhan untuk mengembangkan keahlian 
masyarakat agar mampu meningkatkan pengendalian atas keputusannya, sumber-sumber serta struktur yang mempengaruhi kehidupannya. Dalam hal ini perubahan dalam hubungan kekuasaan (power relationship) merupakan prioritas, yang diperlukan untuk mencapai tujuan-tujuan pembangunan di negara sedang berkembang.

Pendidikan nonformal sebagai proses pemberdayaan (empowering), dapat dikembangkan melalui sejumlah tahapan. Pertama, orang-orang harus mengembangkan kesadaran bahwa mereka bisa mengambil tindakan untuk memperbaiki kehidupannya dan memerlukan keahlian untuk bisa melakukan tindakan tersebut. Kedua, melalui tindakan tersebut, orang mulai menghilangkan kelemahannya dan meningkat kepercayaan dirinya. Akhirnya, dengan keahlian dan kepercayaannya itu yang terus tumbuh dan berkembang, orang-orang dapat bekerja bersama untuk mampu memberi pengaruh yang lebih besar atas keputusan dan sumber-sumber yang mempengaruhi kesejahteraan mereka. Pendidikan nonformal sebagai proses pemberdayaan, adalah suatu bentuk pendidikan yang dapat diarahkan pada perubahan sistem, daripada hanya perubahan individual (Kindervatter, 1979: 43-44).

Terkait dengan pendidikan sebagai proses pemberdayaan, tampaknya sangat jelas Koperasi sebagai sebuah sistem sosio ekonomi adalah "kendaraan" yang dapat digunakan untuk tujuan itu. Sebagaimana ditunjukkan oleh prinsip Koperasi, salah satu prinsip Koperasi adalah pendidikan, pelatihan dan informasi. Koperasi pun sering dijuluki sebagai "school of democracy".

\subsection{Kelembagaan Masyarakat Daerah Tertinggal}

Penanggulangan daerah tertinggal merupakan issue global di samping issue kemiskinan yang selalu menjadi perhatian baik secara nasional maupun internasional. Secara umum penyebab ketertinggalan daerah itu adalah tidak terdapatnya potensi yang bisa dikembangkan dan letak geografis yang sulit dijangkau sehingga prasarana sulit disediakan. Arah pengembangan kawasan tertinggal adalah pemberdayaan masyarakat secara komprehensif dan partisipatif yang mencakup penyediaan fasilitas pendidikan, kesehatan, dan prasarana dasar.

Di sisi lain, masalah daerah tertinggal di Indonesia saat ini dirasakan sudah sangat mendesak untuk ditangani. Khususnya di wilayah perdesaan, ciri dan penyebab umum dari kondisi daerah tertinggal adalah:

- Geografis. Umumnya secara geografis daerah tertinggal relatif sulit dijangkau karena letaknya yang jauh di pedalaman, perbukitan/ pegunungan, kepulauan, pesisir, dan pulau-pulau terpencil atau karena faktor geomorfologis lainnya sehingga sulit dijangkau oleh jaringan baik transportasi maupun media komunikasi.

- Sumberdaya Alam. Beberapa daerah tertinggal tidak memiliki potensi sumberdaya alam, daerah yang memiliki sumberdaya alam yang besar namun lingkungan sekitarnya merupakan daerah yang dilindungi atau tidak dapat dieksploitasi, dan daerah tertinggal akibat pemanfaatan sumberdaya alam yang berlebihan.

- Sumberdaya Manusia. Pada umumnya masyarakat di daerah tertinggal mempunyai tingkat pendidikan, pengetahuan, dan keterampilan yang relatif rendah serta kelembagaan adat yang belum berkembang.

- Prasarana dan Sarana. Keterbatasan prasarana dan sarana komunikasi, transportasi, air bersih, irigasi, kesehatan, pendidikan, dan pelayanan lainnya yang menyebabkan masyarakat di daerah tertinggal tersebut mengalami kesulitan untuk melakukan aktivitas ekonomi dan sosial.

- Daerah Rawan Bencana dan Konflik Sosial. Seringnya suatu daerah mengalami bencana alam dan konflik sosial dapat menyebabkan terganggunya kegiatan pembangunan sosial dan ekonomi.

- Kebijakan Pembangunan. Suatu daerah menjadi tertinggal dapat disebabkan oleh beberapa kebijakan yang tidak tepat seperti kurang memihak pada pembangunan daerah tertinggal, kesalahan pendekatan dan prioritas pembangunan, serta tidak dilibatkannya kelembagaan masyarakat adat dalam perencanaan dan pembangunan.

Berbagai upaya program/pola/ kegiatan untuk pembangunan daerah tertinggal banyak dilakukan (baik secara khusus maupun secara umum), mulai dari Program Bimas dan Inmas dalam rangka swasembada 
pangan, Inpres, IDT, hingga JPS. Namun demikian umumnya program-program tersebut dianggap tidak mampu menyelesaikan permasalahan di daerah tertinggal secara tuntas, rentannya perekonomian masyarakat terhadap krisis ekonomi yang terjadi telah menyadarkan para perencana program pembangunan daerah tertinggal akan kurang diperhatikannya aspek keberlanjutan dan kemandirian masyarakat dalam program-program pembangunan daerah tertinggal yang lalu. Untuk itu dirasakan perlu adanya upaya pemberdayaan institusi komunitas agar masyarakat mampu mengelola upaya pembangunan daerah tertinggal secara mandiri dan berkelanjutan.

Berbekal kesadaran bahwa pembangunan daerah tertinggal merupakan masalah yang harus diatasi dan menjadi tanggung jawab bersama, sudah selayaknya semua pihak bahu membahu untuk mengatasinya, dan menuju sinergi berbagai pihak untuk "bersama membangun kemandirian" dalam pembangunan daerah tertinggal. Pendekatan dan cara yang dipilih dalam pembangunan daerah tertinggal selama ini perlu diperbaiki yaitu ke arah pengokohan kelembagaan masyarakat. Keberdayaan kelembagaan masyarakat tersebut dibutuhkan dalam rangka membangun organisasi masyarakat warga yang benar-benar mampu menjadi wadah perjuangan masyarakat daerah tertinggal, yang mandiri, berkelanjutan dalam menyuarakan aspirasi serta kebutuhan mereka dan mampu mempengaruhi proses pengambilan keputusan yang berkaitan dengan kebijakan publik di tingkat lokal, baik dari aspek sosial, ekonomi maupun lingkungan.

2.3. Program Swasembada Garam Nasional

2.3.1. Latar Belakang

Indonesia adalah negara kepulauan yang memiliki lahan pegaraman potensial sekitar 34.731 ha dan sampai tahun 2009 lahan produktif sekitar 20.089 ha. Lahan pegaraman tersebut tersebar di 9 (sembilan) Propinsi yaitu Jawa Timur, Jawa Barat, Jawa Tengah, NTB, NTT, Sulawesi Selatan dan Sulawesi Tengah, Bali dan Aceh.

Garam merupakan komoditi strategis sebagai bahan baku industri dan bahan pangan yang tidak dapat digantikan. Pemenuhan kebutuhan garam nasional sampai saat ini sebagian masih diimpor. Permasalahan pegaraman nasional antara lain menyangkut produktifitas dan kualitas serta tataniaga garam. Harga garam di tingkat petambak relatif rendah mengakibatkan rendahnya tingkat kesejahteraan petambak garam sehingga banyak petambak yang beralih menekuni mata pencaharian lain. 


\section{PERCEPATAN PEMBANGUNAN SOSIAL EKONOMI DAERAH TERTINGGAL}

\section{(DOSEDT)}
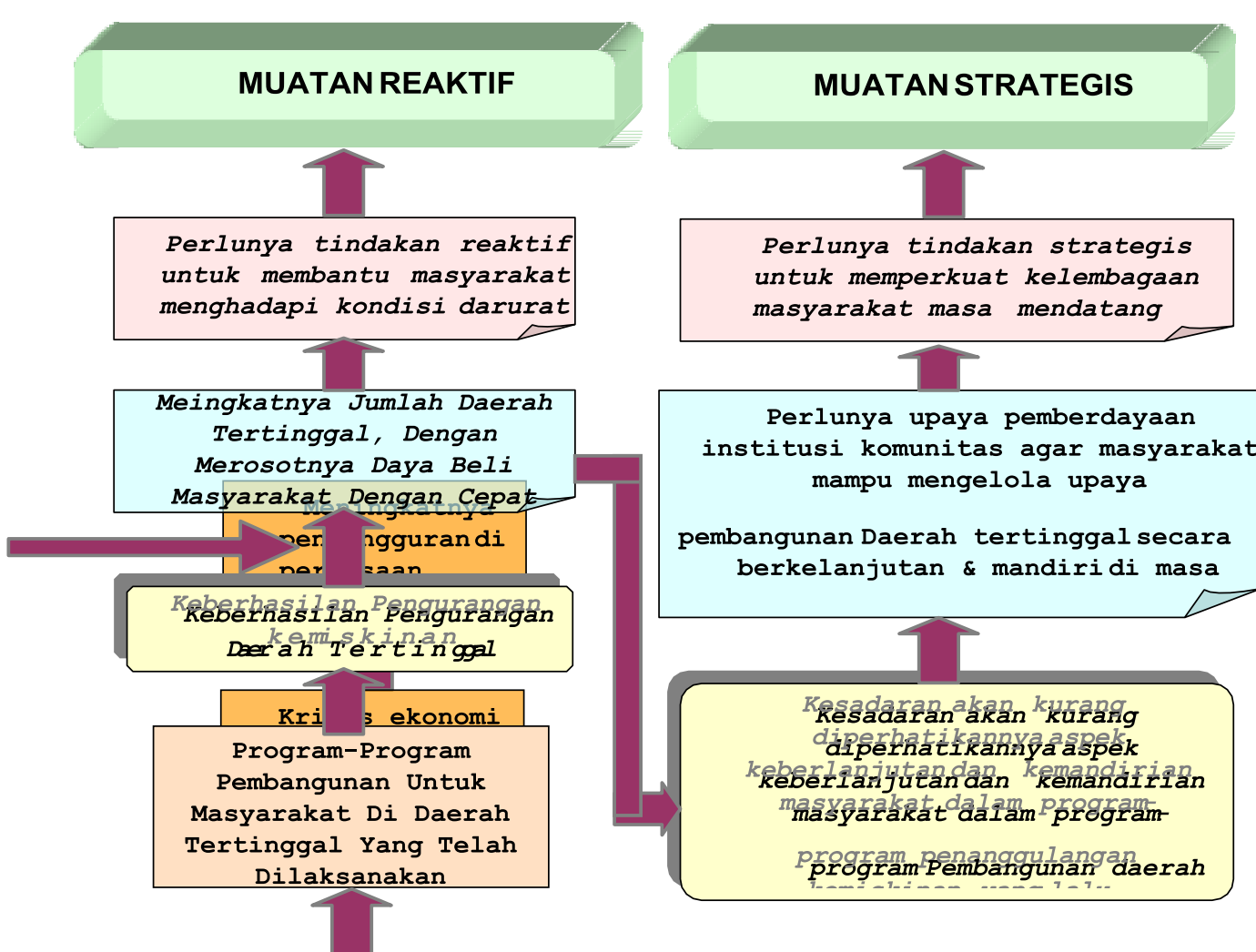

DAERAH TERTINGGAL DI INDONESIA

Gambar 2.4 Pembangunan Masyarakat di Daerah Tertinggal di Indonesia 
Kebutuhan garam setiap tahun meningkat sekitar 2-4\% per tahun untuk garam kelompok non-CAP dan $4 \%$ per tahun untuk garam kelompok CAP. Produksi garam tahun 2007 sebesar 1.300.000 ton, tahun 2008 sebesar 1.030 .000 ton dan tahun 2009 sebesar 1.100 .000 ton, produksi pada kondisi iklim normal adalah sebesar 1.200.000 ton. Fluktuasi dan penurunan produksi garam dalam negeri bervariasi sesuai dengan kondisi iklim dan juga diakibatkan oleh kurang terpeliharanya ladang pegaraman, konversi ladang pegaraman menjadi non-pegaraman khususnya di sentra garam yang berlokasi dekat dengan perkotaan seperti di pantai Utara Jawa dan Madura.

Total kebutuhan garam nasional pada tahun 2009 untuk konsumsi rumah tangga dan industri aneka pangan sebesar 970.000 ton, perminyakan sebesar 100.000 ton, industri tekstil dan kulit sebesar 96.000 ton, industri Chlor Alkali Plan (CAP) sebesar 1.150.100 ton dan industri farmasi 100 ton. Sekitar 1.600.000 ton garam harus diimpor untuk memenuhi kebutuhan tersebut.

Berkenaan dengan hal tersebut di atas, pemerintah pada tahun anggaran 2010 telah mencanangkan swasembada garam nasional melalui produksi dalam negeri. Swasembada garam nasional dilakukan dengan pendekatan : (i) pemenuhan kebutuhan garam konsumsi (kelompok Non-CAP) yaitu garam untuk keperluan konsumsi rumah tangga dan sejenisnya termasuk garam diluar kebutuhan industri Chlor Alkali Plant (CAP) seperti garam untuk pengasinan ikan, industri makanan, industri pakan ternak, industri pengeboran minyak, industri penyamakan kulit dan industri tekstil; dan (ii) pemenuhan kebutuhan garam untuk industri CAP (kelompok CAP) termasuk industri pharmaceutical.

Potensi lahan garam di Indonesia dapat dilihat pada Gambar 2.5. 


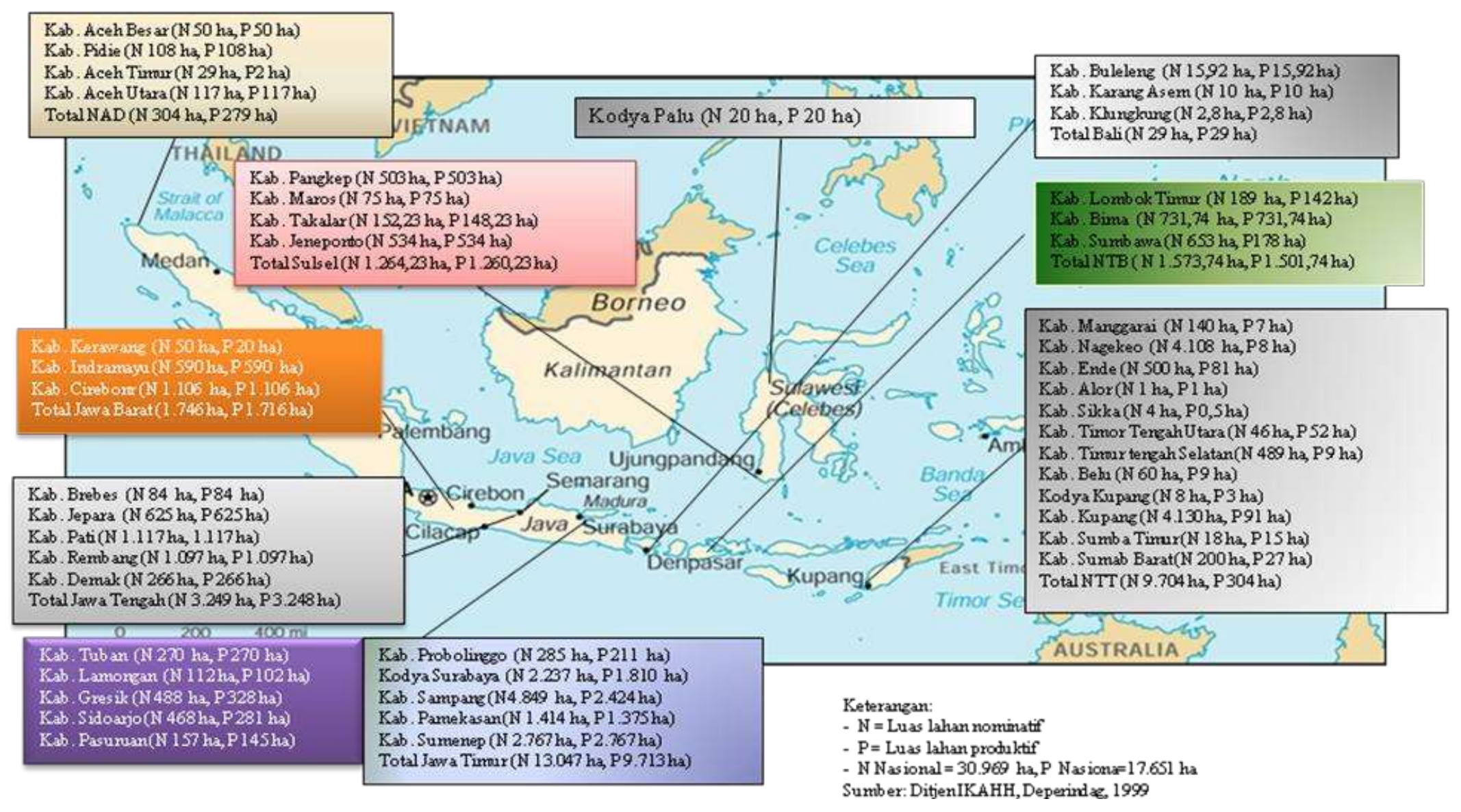

Gambar 2.5 Potensi Lahan Garam di Indonesia 
2.3.2. Metode Pencapaian Swasembada Garam Nasional

Pencapaian swasembada Garam Konsumsi pada TA 2012 dan Garam Industri pada TA 2015 dilakukan dengan metode sebagai berikut :

1. Optimalisasi ladang pegaraman produktif melalui intensifikasi dan revitalisasi dalam rangka peningkatan produksi Garam Konsumsi. Fokus kegiatan di Madura dan Pantura Jawa.

2. Optimalisasi ladang pegaraman produktif melalui ekstensifikasi dalam rangka peningkatan produksi Garam Industri. Fokus kegiatan di Wilayah Timur Indonesia.

2.3.3. Strategi Pencapaian Swasembada Garam Nasional

Strategi pencapaian Swasembada Garam Nasional adalah sebagai berikut :

1. Pemerintah berperan aktif dalam mengkoordinasikan dan pengalokasian anggaran pada pelaksanaan optimalisasi lahan garam produktif melalui intensifikasi dan revitalisasi untuk peningkatan produksi Garam Konsumsi (Non-CAP) di Madura dan Pantura Jawa serta ekstensifikasi dengan pendekatan kemitraan usaha yang melibatkan pihak swasta sebagai perusahaan inti dan petambak garam sebagai plasma untuk pencapaian swasembada garam industri CAP pada tahun 2015.

2 Melakukan upaya pemberdayaan masyarakat melalui pembentukan Desa Garam (sentra garam, koperasi dan kemitraan Pola PIR), kebijakan tata niaga (kelancaran distribusi dan harga yang layak), pengembangan kelembagaan (Pelatihan dan pendampingan bidang manajemen dan teknik produksi), menyusunan Skema pendanaan (untuk kemudahan akses pembiayaan)

2.3.4. Arah Kebijakan

Arah kebijakan dalam pencapaian Swasembada Garam Nasional adalah :

1. Koordinasi dengan kementerian dan institusi terkait di tingkat pusat dan daerah untuk meningkatkan produktifitas dan kualitas garam.

2. Pengembangan infrastruktur lahan tambak, alat produksi, pelabuhan, irigasi, pergudangan dan jalan usaha tani.

3. Pengembangan Desa Garam

4. Pembinaan dan bimbingan teknis bagi masyarakat petambak dalam penerapan teknologi produksi garam dan pengelolaan pasca panen.

5. Penataan tata niaga garam

6. Akses permodalan dan kerjasama dengan lembaga-lembaga keuangan mikro penunjang modal

\subsubsection{Kelembagaan}

Kelembagaan dalam pencapaian swasembada garam nasional dirancang berjenjang dari tingkat pusat sampai pelaksana di lapangan dengan melibatkan intansi terkait dalam bentuk :

1. Badan Swasembada Garam Nasional (BSGN) yang merupakan lembaga bersifat adhoc, dibentuk melalui Surat Keputusan Presiden atau Surat Keputusan Menteri Koordinator Perekonomian dengan masa tugas selama pelaksanaan program Swasembada Garam Nasional. Keanggotaan BSGN adalah wakil-wakil yang ditunjuk oleh Kementerian terkait serta Bupati pelaksana program Swasembada Garam Nasional.

2. Dewan Garam Indonesia (DGI) adalah pembina di tingkat pusat yang keanggotaannya terdiri dari Menteri terkait yaitu Menteri Kelautan dan Perikanan, Menteri Perindustrian, Menteri Perdagangan, Menteri Dalam Negeri, Menteri Keuangan dan Menteri Negara BUMN. Tugas utama DGI adalah (i) memantau dan mengkoordinasikan kegiatan manajemen pembinaan usaha pegaraman nasional antar Kementerian melalui kebijakan dan implementasi pembinaan usaha pegaraman nasional yang terpadu dan komprenhensif. (ii) memantau kegiatan impor dan distribusi garam.

\section{4 .}

Memahami Konsep Koperasi

Sebelum membahas lebih lanjut bagaimana koperasi harus dikembangkan, terlebih dahulu perlu dikemukakan pengertian koperasi yang tepat. Hal ini diperlukan karena istilah koperasi masih sering dipahami secara berbeda yang berakibat salah penilaian dan pada akhirnya salah mempraktekkan koperasi sesuai dengan nilai-nilai, kaidah-kaidah, dan prinsip-prinsipnya. Di antara sekian banyak pemikiran, berikut dikemukakan beberapa pemikiran mengenai koperasi.

Menurut Marvin Schaar (1980:7), “A cooperative is a business voluntarily owned and controlled by its member patrons, and operated for them and by them on a nonprofit or cost basis". (Koperasi 
adalah sebuah bisnis yang dimiliki secara sukarela dan dikendalikan oleh anggotanya, dioperasikan untuk dan oleh mereka berdasarkan tujuan bukan mencari laba atau dioperasikan berdasarkan biayanya). Selanjutnya untuk menentukan apakah suatu organisasi, Koperasi atau bukan Marvin (1980:7) menyusun kriteria yang dikembangkan berdasarkan hasil studi Farmer Cooperative Service (FCS), sebagai berikut :

1. Apakah organisasi menyediakan keuntungan ekonomi bagi anggotanya, termasuk keuntungan pendidikan, sosial atau lainnya?

2. Apakah perusahaan pada dasarnya bersifat nonprofit? Artinya, keuntungan (manfaat) untuk para anggotanya, bukan untuk organisasi atau anggota sebagai investor?

3. Apakah organisasi dikendalikan oleh orang-orang yang menjadi penggunanya?. Setiap anggota umumnya memiliki satu suara yang sama, dengan tidak mempertimbangkan volume bisnis atau saham yang dimilikinya di koperasi, meskipun kadang-kadang terjadi juga pengendalian didasarkan pada volume transasksi bisnis dengan Koperasi.

4. Apakah organisasi memusatkan kegiatannya pada kepentingan bersama para anggotanya?

Bila jawaban atas pertanyaan di atas, semuanya ya, maka itulah Koperasi yang sebenarnya. Sementara itu, Samuel Chukwu (1990:1), menyatakan bahwa "In narrow sense, however, the term cooperation is also often used to mean the activities of a specific form or organization, the cooperative/the cooperative society. In that sense, a study of cooperation is a study of the cooperative institution and its activities" (Dalam arti sempit, istilah Koperasi sering juga digunakan untuk menggambarkan suatu kegiatan dari bentuk khusus atau organisasi Koperasi. Dalam pengertian ini studi tentang Koperasi berarti studi tentang lembaga Koperasi dan kegiatannya). Selain itu, Chukwu pun mendaftar sejumlah definisi tetang Koperasi. Dalam hal ini, Ia berhasil mengumpulkan 19 definisi. Selanjutnya, kesembilan belas definisi ini dikelompokkan menjadi dua.

Pertama, definisi yang menggunakan pendekatan "the essentialist" dan kedua, yang menggunakan pendekatan "the nominalist". Yang pertama, ...the essentialist approach attempts to define cooperatives in terms of values, idiologies and overall economic and social goal which are to be persued (pendekatan esensialis berusaha mendefinisikan koperasi berdasarkan nilai-nilai dan keseluruhan tujuan ekonomi dan sosial yang ingin diperjuangkan). Sedangkan Nominalist approach attempts to define them by picking out certain, mainly structural elements of organization which are seen to be common to all institutions which claim be cooperative. (pendekatan nominalis berusaha mendefinisikan koperasi dengan mengenali struktur utama organisasi yang tampak sebagai sesuatu yang umum bagi lembaga yang mengaku dirinya sebagai koperasi).

Keterbatasan pendekatan esensialis muncul dari kenyataan bahwa nilai-nilai, tujuan dan idiologi dari tiap-tiap sistem ekonomi atau bangsa tentu berbeda satu sama lain. Dengan kata lain tak ada definisi esensialis yang dapat berlaku untuk seluruh koperasi di dunia, dan karenanya tidak cocok sebagai pijakan untuk suatu analisis. Di sisi lain, definisi nominalis yang didasarkan pada elemenelemen struktural, menghindari kelemahan semacam itu. Dalam hal ini, pendekatan nominalis mengembangkan empat elemen struktural organisasi koperasi sebagai berikut (Hanel, 1989:29; Chukwu, 1990:2) :

1. Para individu yang mengoperasikan perusahaan atau rumah tangga masing-masing, yang terikat oleh sekurang- kurangnya satu kepentingan yang sama (kelompok orang).

2. Tindakan bersama oleh kelompok untuk mencapai tujuan kelompok melalui perbaikan ekonomi anggota masing-masing (tolong menolong).

3. Perusahaan yang dimiliki bersama dalam jangka panjang sebagai alat (sarana) untuk menghasilkan barang dan jasa (perusahaan koperasi).

4. Hubungan yang bersifat promosi antara perusahaan atau rumah tangga para anggota dengan perusahaan koperasi yang diberi tugas untuk itu dengan menghasilkan barang dan jasa (promosi kesejahteraan anggota)

Keempat komponen struktural tersebut dapat gambarkan di bawah ini, yang oleh Hanel (1989:29) disebutnya organisasi koperasi sebagai suatu sistem sosial ekonomi, atau menurut Dulfer, (1986:35) sebagai "a socio-technolgical system as to its substance, an open system as to its 
environment, a target based system as to its mode of function, an economic system as to the use of its resources".

Pengertian koperasi yang lebih baru, dikemukakan oleh aliansi Koperasi sedunia atau International Cooperative Alliance (ICA), melalui Statement on The Cooperative Identity, yang disepakati para peserta Konferensi ICA, yang diselenggarakan di Manchester, tahun 1995. Berdasarkan hasil konferensi tersebut, jati diri koperasi dijelaskan oleh tiga hal, yaitu definisi, nilai-nilai dan prinsip-prinsip, yang dikutip secara lengkap berdasarkan publikasi ICA sebagai berikut di bawah ini. 


\section{Definition}

A co-operative is an autonomous association of persons united voluntarily to meet their common economic, social and cultural needs and aspirations through a jointly-owned and democraticallycontrolled enterprise.

Perusahaan koperasi

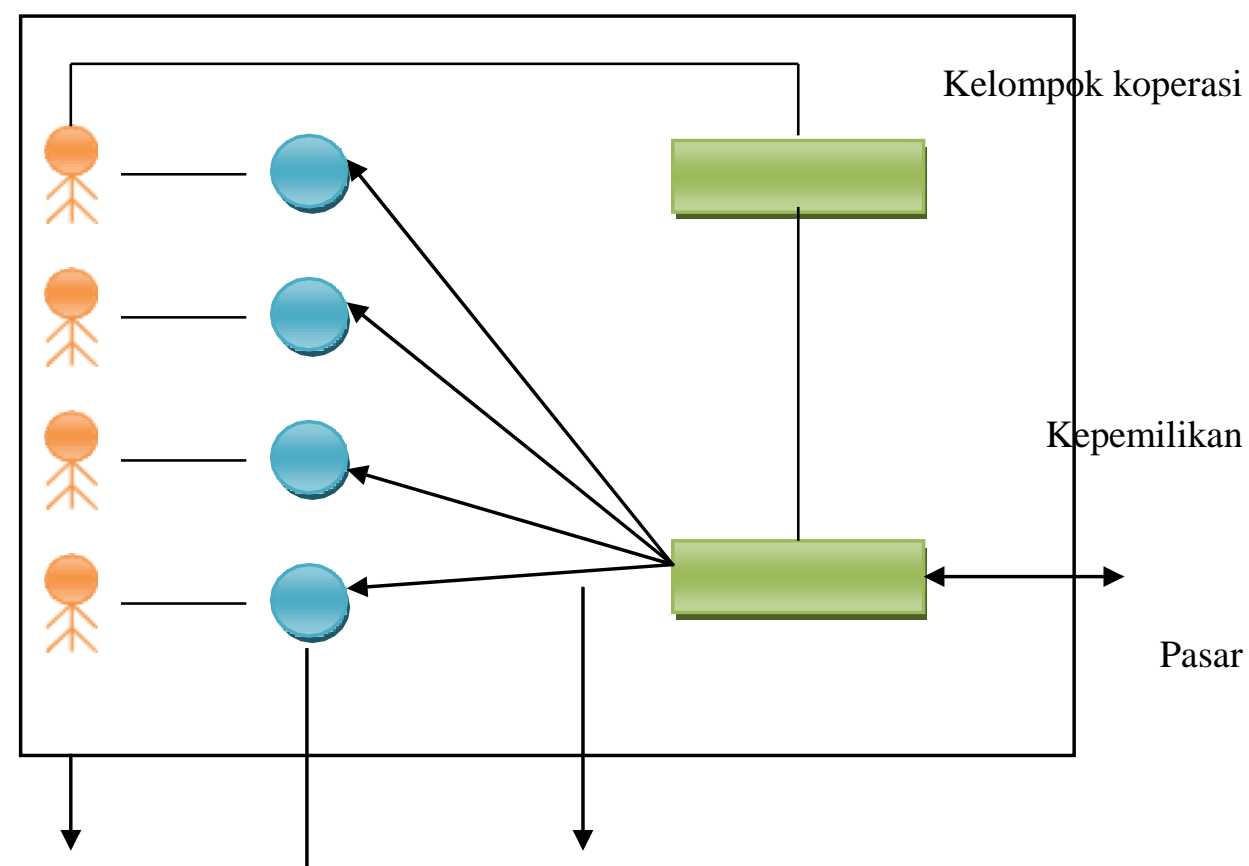

Anggota sebagai pemillkepelangganan (promosi anggota) sebagai

pelanggan

Kepentingan ekonomi (perusahaan) anggota

Gambar 2.6. Koperasi sebagai Organisasi Sosial Ekonomi

\section{Values}

Co-operative are based on the values of self-help, self-responsibility, democracy, equality, equity and solidarity. In the tradition of their founders, co-ooperative members believe in the ethical values of honesty, openness, social responsibility and caring for others. 


\section{Principles}

The co-operative principles are guidelines by which cooperatives put their values into practice.

$I^{\text {st }}$ Principle : Voluntarily and open Membership

Co-operatives are voluntarily organisation, open to all persons able to use their service and willing to accept the responsibilities of membership, without gender, social, racial, political or religious discrimination.

$2^{\text {nd }}$ Principle : Democratic Member Control

Co-operative are democratic organisation controlled by their members, who actively participate in setting their policies and making decisions. Men and women serving as elected representatives are accountale to the membership. In primary co-operative member have equal voting rights (one member, one vote) and co-operative at other levels are also organized in a democratic manner.

$3^{\text {rd }}$ Principle : Member Economic Participation

Members contribute equitably to, and democratically control, the capital of their co-operative. At least part of that capital is usually the common property of the co-operative. Members usually receive limited compensation, if any, on capital subscribed as a condition of membership. Members allocate surpluses for any or all of the following purposes : developing their co-operative, possibly by setting up reserves, part of which at least would be indivisible; benefiting members in proportion to their transactions with the co-operative; and supporting other activities approved by the membership.

$4^{\text {th }}$ Principle : Autonomy and Independence

Co-operatives are autonomous, self help organisation controlled by their members. If they enter into agreements with other organizations, including governments, or raise capital from external sources, they do so in terms that ensure democratic control by their members and maintain their co-operative otonomy.

$5^{\text {th }}$ Principle : Education, Training and Information 
Co-operatives provide education and training for their members, elected representatives, managers, and employees so they can contribute effetivelly to the development of their cooperatives. They inform the general public-particularly young people and opinion leaders-about the nature and benefits of co-operation.

$6^{\text {th }}$ Principle : Co-operation among Co-operatives

Co-operatives serve their members most effectively and strengthen the co-operative movement by working together through local, national, regional and international structure.

$7^{\text {th }}$ Principle : Concern for Community

Co-operatives work for the sustainable development of the communities through policies approved by their members.

Berdasarkan kutipan di atas jelaslah bahwa Koperasi adalah perkumpulan otonom dari orangorang yang bersatu secara sukarela untuk tujuan memenuhi kebutuhan ekonomi, sosial, budaya dan aspirasi bersama, melalui perusahaan yang dimiliki bersama dan dikendalikan secara demokratis. Di dalam prakteknya koperasi tersebut menjalankan nilai-nilai: menolong diri sendiri (swadaya), tanggung jawab pribadi, demokrasi, keadilan, persamaan dan solidaritas, di samping nilai-nilai kejujuran, keterbukaan, tanggung jawab sosial dan peduli pada masyarakat, sebagai tradisi para pelopor Koperasi di masa lalu. Kegiatan itu kemudian dibingkai oleh prinsip-prinsip koperasi yang menjadi pedoman operasionalnya, yaitu: keanggotaan terbuka dan sukarela, pengendalian oleh anggota secara demokratis, partisipasi ekonomi anggota, otonom dan mandiri (independen), pendidikan, pelatihan dan informasi, kerjasama di antara sesama koperasi dan kepeduliaan kepada masyarakat. 


\subsubsection{Konsepsi Pembangunan Koperasi}

Seberapa penting koperasi bagi pembangunan masyarakat ? Konferensi Umum International Labour Organization dan International Labour Office, pada 1 Juni 1966, menegaskan bahwa :

1. Pembentukan dan pertumbuhan koperasi harus dipandang sebagai salah satu instrumen penting bagi pembangunan ekonomi, sosial dan budaya, maupun bagi kemajuan manusia di negara-negara sedang berkembang.

2 Secara khusus, koperasi harus didirikan dan dikembangkan sebagai sarana :

a. untuk memperbaiki situasi ekonomi, sosial dan budaya dari mereka yang memiliki sumber daya dan kesempatan yang terbatas dan juga untuk membangkitkan semangat mereka untuk berkarya.

b. untuk meningkatkan sumber dana pribadi dan nasional melalui usaha- usaha yang mengarah kepada pembentukan modal, pemanfaatan kredit secara sehat dan menghilangkan riba.

c. untuk memberikan kontribusi terhadap pertumbuhan ekonomi melalui peningkatan pengawasan secara demokratis atas kegiatan-kegiatan ekonomi dan atas pembagian pembangunan secara adil.

d. untuk meningkatkan pendapatan nasional, penerimaan ekspor dan penciptaan lapangan kerja dengan memanfaatkan sumber daya secara penuh, misalnya melalui penerapan sistem pembaharuan agraris dan sistem permukiman yang ditujukan untuk mengolah daerah-daerah baru menjadi kawasan yang produktif dan untuk mengembangkan kawasan industri, sebaiknya tersebar yang mengolah bahan baku setempat.

e. untuk memperbaiki kondisi sosial seperti menunjang pelayanan sosial untuk perumahan, dan jika mungkin kesehatan, pendidikan dan komunikasi.

f. untuk membantu meningkatkan pengetahuan umum dan ketrampilan teknis etani jpara anggotanya. 
3. Pemerintah Negara-negara berkembang agar merumuskan dan menerapkan kebijakan yang memungkinkan koperasi memperoleh bantuan ekonomi, keuangan, teknik, hokum dan lainnya tanpa merusak kemandiriannya.

4. Dalam menerapkan kebijakan itu perlu dipertimbangkan kondisi sosial ekonomi, sumber daya yang tersedia dan peran yang dapat dimainkan oleh koperasi dalam pembangunan Negara yang besangkutan.

5. Kebijakan tersebut perlu diintegrasikan kedalam rencana pembangunan sepanjang hal itu sesuai dengan ciri dan prinsip pokok koperasi.

6. Kebijakan itu harus selalu ditinjau ulang untuk disesuaikan dengan perubahan- perubahan di bidang ekonomi, sosial dan kemajuan teknologi.

7. Gerakan Koperasi perlu dilibatkan dalam perumusan dan jika mungkin dalam pelaksanaan kebijakan tersebut.

Apa yang dikemukakan di atas kemudian mendapat dukungan Resolusi PBB 2459 (XXIII), tahun 1968 dan No VII tahun 1983, yang berulang kali memberikan rekomendasi mengenai perlunya peningkatan kemampuan koperasi sebagai salah satu sarana penting bagi pembangunan ekonomi, sosial dan budaya seluruh anggota masyarakat.

2.4.2. Proses Kewirausahaan Koperasi

Dengan mengutip Robert and Weiss (1988), Ropke (1992:25) mengemukakan 4 langkah dalam proses kewirausahaan koperasi yaitu sebagai berikut :

1. Opportunity Search (Pencarian Peluang)

Dari mana peluang Koperasi berasal? Pencarian peluang merupakan langkah pertama proses kewirausahaan untuk secara berhasil mengimplementasikan gagasan baru. Usaha ini dilakukan dengan mengidentifikasi peluang, dari mana pun sumbernya. 


\section{Opportunity Assesment (Penilaian Peluang)}

Peluang yang mana yang menjanjikan potensi manfaat paling besar bagi para anggota dan calon anggota.Tujuan penilaian peluang adalah untuk memilih peluang yang paling baik di antara peluangpeluang yang ada.

3. Opportunity Development (Pengembangan Peluang)

Peluang mana yang muncul sebagai hasil penilaian yang dapat dikembangkan lebih lanjut. Pada langkah ini, kemudian peluang-peluang yang memiliki potensi yang tinggi dianalisis secara kritis, khususnya factor-faktor kritis dan tindakan-tindakan yang pada akhirnya harus diambil, diidentifikasi.

4. Opportunity Pursuit (Implementasi)

Ini berkaitan dengan bagaimana peluang yang terpilih harus diimplementasikan. Tahap ini dapat dianggap sebagai proses merencanakan agar peluang dapat direalisasikan.

Sebagaimana telah dikemukakan bahwa fungsi kewirausahaan koperasi adalah mencari peluang dan mengimplementasikannya untuk memecahkan masalah anggota, yang berarti pula mempromosikan anggotanya. Dalam hal ini wirausaha koperasi harus mampu menghasilkan keuntungan komparatif dan kompetitif melalui peluang-peluang yang diciptakannya.

Hasil studi David McClelland (1964) dalam Suwarsono(2000) mengenai kewirausahaan, dapat ditambahkan sejumlah kompetensi lain wirausaha, sebagai berikut:

\section{Proactivity (Proaktif)}

1. Initiative, inisiatif. Melakukan sesuatu sebelum diminta atau dipaksa keadaan.

2. Assertiveness, asertif. Menghadapi masalah dengan orang lain secara lugas. Katakan kepada orang tersebut apa yang harus dilakukan. 


\section{Achievement Orientation (Orientasi Pencapaian)}

1. Sees and acts on opportunities, melihat dan bertindak berdasarkan peluang. Meraih peluang yang tidak biasa untuk memulai suatu bisnis baru, memperoleh kekuangan, tanah atau bantuan.

2. Efficiency orientation, orientasi efisiensi. Mencari atau menemukan cara-cara melakukan dengan lebih cepat atau lebih murah.

3. Concern for high quality work, peduli pada kerja yang berkualitas tinggi. Berketetapan untuk menghasilkan atau menjual produk-jasa yang berkualitas tinggi.

4. Systematic Planning, perencanaan yang sistematis. Memecah suatu tugas besar kedalam pekerjaanpekerjaan yang lebih kecil; mengantitipasi kemungkinan hambatan; mengevaluasi alternatif.

5. Monitoring, monitoring. Mengembangkan atau menggunakan prosedur untuk menjamin tugas pekerjaan dapat diselesaikan, atau pekerjaan memenuhi standar yang telah ditetapkan.

\section{Commitment to others (Berpegang teguh pada janji)}

1. Commitment to work contract, berpegang teguh pada kontrak kerja. Berusaha keras untuk memenuhi kontrak yang telah disepakati.

2. Recognizing the importance of business relationship, menyadari pentingnya hubungan bisnis. Berupaya untuk membangun hubungan pertemanan dengan para pelanggan. Melihat hubungan antarpribadi sebagai sumber bisnis utama. Menempatkan tujuan jangka panjang daripada perolehan jangka pendek. 


\section{METODOLOGI}

\subsection{Pendekatan Umum}

Output pekerjaan ini adalah Rumusan Kebijakan tentang Penguatan Kelembagaan Koperasi khususnya petani garam di kabupaten daerah tertinggal (Kabupaten Sampang, Pamekasan dan Bangkalan), yang akan dijadikan sebagai pedoman untukmenguatkan lembaga-lembaga koperasi petani garam sehingga dapat meningkatkan peran serta/partisipasi masyarakat perdesaan dalam pemberdayaan ekonomi lokal, serta untuk pedoman sinergitas antar stakeholder dalam upaya peningkatan kapasitas kelembagaan koperasi masyarakat petani garam, di daerah studi dalam rangka meningkatkan pendapatan dan taraf hidup mereka.

Untuk mencapai tujuan studi yaitu rumusan kebijakan untuk perkuatan kelembagaan koperasi petani garam, maka akan dilakukan studi secara mendalam yang didasarkan pada data yang diperoleh dari hasil riset dengan desain tertentu. Desain riset adalah kerangka atau framework untuk mengadakan penelitian yang didalamnya tercakup penjelasan secara terperinci mengenai tipe desain riset yang memuat prosedur yang sangat dibutuhkan dalam upaya memperoleh informasi serta pengolahannya dalam rangka memecahkan masalah.

3.2. Studi Pustaka dan Pengumpulan Data

Sekunder

Studi kepustakaan dimaksudkan untuk memperoleh informasi mengenai konsep- konsep yang terkait dengan pengembangan usaha petani/kelompok petani garam, kelembagaan ekonomi/koperasi, pemberdayaan masyarakat, community development, teknologi, pengembangan wilayah, kebijakan pengembangan 
penggaraman nasional, tata niaga propinsi maupun daerah dan peraturan-peraturan yang berlaku terkait dengan aktivitas usaha kecil/koperasi dan perlindungan terhadap masyarakat petani garam yang termasuk dalam golongan ekonomi lemah.

Sedangkan pengumpulan data sekunder dalam tahap persiapan ini dimaksudkan untuk melihat besaran dan kedalaman masalah yang akan menjadi fokus perhatian. Masalah tersebut kemudian didekati dengan menggunakan sejumlah konsep (teori) melalui studi pustaka, sehingga diperoleh kerangka pikir yang jelas yang menjadi arah program dan kegiatan.

\subsection{Koordinasi dengan Instansi Terkait}

Dalam pelaksanaan pekerjaan ini akan dilakukan koordinasi dengan unit-unit kerja di lingkungan Kantor Kementerian Pembangunan Daerah Tertinggal, Kementerian Koperasi dan UKM, Kementerian Kelautan dan Perikanan, Kementerian Perindustrian, Kementerian Perdagangan dan instansi-instansi terkait lainnya baik di Pusat maupun Daerah.

3.4. Survey Lapang dan Survey Instansional

Survey lapang dilakukan untuk mengevaluasi kebijakan, program pembangunan, pertumbuhan ekonomi (industri), pertumbuhan (kinerja) koperasi. Melalui survey ini diharapkan dapat diketahui potensi (+) yang dimiliki yang perlu ditingkatkan dan dikembangkan, serta permasalahan (-) yang kemudian perlu dianalisis dan dipecahkan. Para ahli dan asisten bisa dibagi tiga sesuai dengan kabupaten yang ada, kemudian evaluasi dilakukan secara simultan, atau evaluasi dilakukan secara bertahap secara bersama-sama per kabupaten.

Survai instansi diarahkan pada unit-unit kerja di lingkungan Bappeda Kabupaten, Dinas Koperasi dan UKM, Dinas Kelautan dan Perikanan , Dinas Perindustrian dan Perdagangan, PN Garam serta instansi terkait lainnya di daerah/propinsi.

3.5. Masukan dari Pakar

Agar pelaksanaan pekerjaan ini dapat menghasilkan keluaran seperti yang diharapkan, maka konsultan akan mengupayakan untuk mendapatkan masukan dari pakar yang terkait dengan pekerjaan ini. Upaya tersebut akan dilakukan baik melalui diskusi formal maupun informal ataupun melalui wawancara.

\subsection{Wawancara}

Wawancara akan dilakukan terhadap para ahli yang mempunyai pengetahuan dan keahlian di bidang pembangunan koperasi, pengembangan usaha dan analisis ekonomi, pengembangan teknologi garam, kelembagaan, psikologi, dan koperasi, sosial budaya dan karakter masyarakat petani garam di wilayah studi baik dengan pakar, pejabat-pejabat dinas terkait dan koperasi, pengamat pembangunan, akademisi dan lainnya, serta birokrat yang terkait langsung dengan penguatan kelembagaan koperasi dan pengembangan garam.

3.7. Workshop /Forum Diskusi/ Partisipasi Para Pemangku Kepentingan

Hasil identifikasi dan evaluasi data primer maupun sekunder dikaji lebih lanjut kemudian dilaporkan, dibahas dan dirumuskan di dalam forum bersama "stakeholder" (pemangku kepentingan) melalui Workshop. Pada forum ini dibahas apa yang diinginkan para peserta, bagaimana mencapainya, rencana aksi, program dijalankan secara berkelanjutan (sustainable). Sejumlah pemegang kepentingan harus hadir atau diwakili pada forum ini, yaitu : para petani garam, pengurus/manajer koperasi, Dekopin/Dekopinda, Pemerintah Daerah, Dinas- Dinas Pemerintahan terkait, Perguruan Tinggi setempat, LSM promotor lembaga swadaya Forum diskusi bisa dilakukan secara berjenjang, disesuaikan dengan batasan waktu dan biaya.

3.8. Diskusi

Untuk mempertajam analisis perlu dilakukan diskusi secara berkala, terutama dengan pemberi pekerjaan, baik secara formal maupun non formal. Secara formal akan diselenggrakan secara berkala 
setiap tahapan pelaporan. 
Gambar 3.1. Alur Pikir dan Kerangka Kerja Studi Penguatan Kelembagaan Koperasi Petani Garam

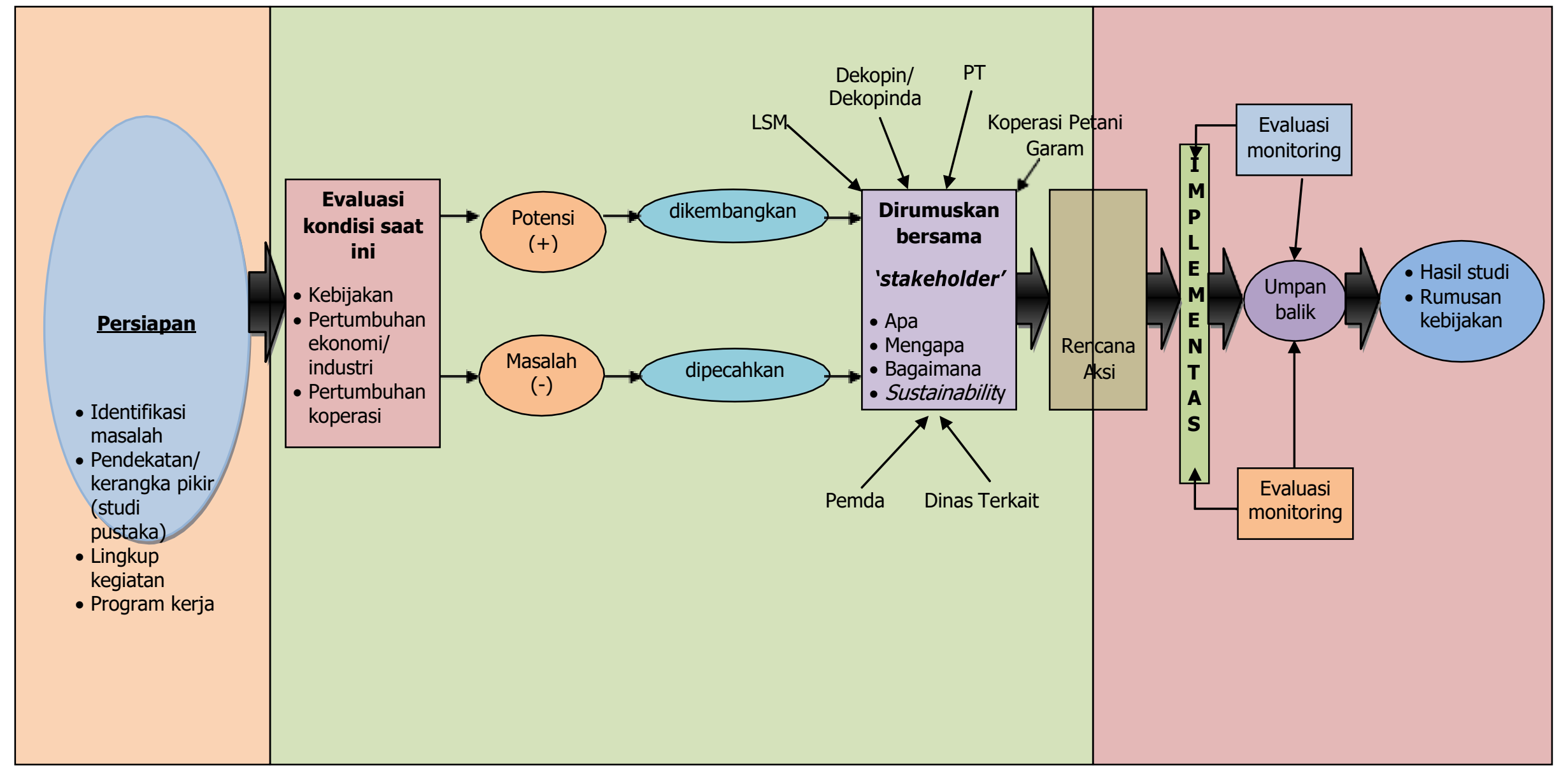




\section{RENCANA KERJA}

Rencana pelaksanaan pekerjaan yang akan dilakukan meliputi 3 tahapan besar yaitu :

1. Tahap Persiapan

2. Tahap Pelaksanaan

3. Tahap Pelaporan

\subsection{Tahap Persiapan}

Kegiatan yang dilakukan pada tahap ini adalah sebagai berikut :

1. Persiapan administrasi proyek

2. Mobilisasi tim pelaksana pekerjaan, sesuai dengan kerangka acuan kerja serta persepsi konsultan terhadap kebutuhan tenaga ahli, maka susunan tim kerja adalah :

a. Ahli Kelembagaan Masyarakat (Team Leader)

b. Ahli Ekonomi

c. Ahli Perkoperasian

d. Ahli Sosiologi

e. Ahli Industri

f. Ahli Manajemen

g. Ahli Organisasi

h. Ahli Kewirausahaan

i. Ahli Pemberdayaan Masyarakat

j. Assisten Ahli Kelembagaan Masyarakat

k. Assisten Ahli Ekonomi

1. Assisten Ahli Perkoperasian

m. Assisten Ahli Sosiologi

n. Assisten Ahli Industri 
o. Assisten Ahli Manajemen

p. Assisten Ahli Organisasi

q. Assisten Ahli Kewirausahaan

r. Assisten Ahli Pemberdayaan Masyarakat

3. Kajian awal dilakukan untuk menterjemahkan tujuan, ruang lingkup dan sasaran akhir studi

4. Melakukan inventarisasi dan pengumpulan data sekunder awal dengan cara melakukan Studi Pustaka, mengenai :

- Peraturan/perundang-undangan terkait dengan kebijakan pengembangan penggaraman nasional, tata niaga propinsi maupun daerah dan peraturan-peraturan yang berlaku terkait dengan aktivitas usaha kecil/koperasi dan perlindungan terhadap masyarakat petani garam yang termasuk dalam golongan ekonomi lemah.

- Konsep-konsep yang terkait dengan pengembangan usaha petani/ kelompok petani garam, kelembagaan ekonomi/koperasi, pemberdayaan masyarakat, community development, teknologi, pengembangan wilayah.

- Potensi dan masalah usaha petani garam serta peluang dan ancaman pengembangan usaha dan kelambagaannya.

Studi-studi terkait lainnya.

5. Menyusun kerangka pikir yang jelas yang menjadi arah program dan kegiatan

6. Melakukan pemahaman bersama yang tepat atas program yang akan dijalankan, agar setiap orang (ahli) mampu memberikan kontribusi optimal sesuai dengan keahlian dan peran yang harus dijalankannya

7. Penyusunan rencana kerja dan metodologi

Berdasarkan kajian atas data sekunder yang ada selanjutnya disusun metodologi dan rencana kerja sesuai dengan hasil yang diharapkan dalam kerangka acuan kerja.

8. Penyusunan kuisioner/checklist yang akan digunakan

9. Koordinasi dengan instansi terkait

10. Penyusunan Laporan Pendahuluan 
Dari hasil kajian sementara, metodologi, rencana kerja, disusun dalam Laporan Pendahuluan sementara yang kemudian dikonsultasikan dengan pihak pemberi pekerjaan.

11. Diskusi dan perbaikan laporan

Laporan Pendahuluan sementara didiskusikan dengan pihak pemberi pekerjaan untuk mendapatkan masukan-masukan, yang kemudian diperbaiki sesuai dengan berita acara diskusi Laporan Pendahuluan.

\subsection{Tahap Pelaksanaan}

Pada tahapan ini konsultan akan melaksanakan orientasi lapangan, identifikasi dan pengumpulan data, sosialisasi, survey lapang, yang kegiatannya diantaranya sebagai berikut :

1. Melakukan identifikasi dan evaluasi kebijakan, program pembangunan, pertumbuhan ekonomi (industri), pertumbuhan (kinerja) koperasi.

2. Survai instansi diarahkan pada unit-unit kerja di lingkungan Bappeda Kabupaten, Dinas Koperasi dan UKM, Dinas Kelautan dan perikanan, Dinas Perindustrian dan Perdagangan, PN Garam serta instansi terkait lainnya di daerah/propinsi.

3. Wawancara mendalam (in-depth interview) yaitu wawancara secara langsung pada seorang responden dengan teknik probing oleh seorang pewawancara yang ahli. Indepth interview digunakan dengan tujuan untuk mendapatkan informasi mengenai hal-hal yang tersembunyi mengenai responden, seperti motivasi, perilaku, perasaan mengenai suatu topik tertentu. untuk mendapatkan informasi secara mendalam, pewawancara bisa bertanya secara informatif dengan menghindari merasa superior dengan menggunakan tekhnik probing.

Wawancara akan dilakukan juga terhadap para ahli yang mempunyai pengetahuan dan keahlian di bidang pembangunan koperasi, pengembangan usaha dan analisis ekonomi, pengembangan teknologi garam, kelembagaan, psikologi, dan koperasi, sosial budaya dan karakter masyarakat petani garam di wilayah studi baik dengan pakar, pejabat-pejabat dinas terkait dan koperasi, pengamat pembangunan, akademisi dan lainnya, serta birokrat yang terkait langsung dengan penguatan kelembagaan koperasi dan pengembangan garam.

4. Observasi yang digunakan untuk menyajikan gambaran realistik perilaku atau kejadian, untuk menjawab pertanyaan, untuk membantu mengerti perilaku manusia, dan untuk evaluasi yaitu melakukan pengukuran terhadap aspek tertentu dalam melakukan umpan balik terhadap pengukuran tersebut.

Unit observasi dilakukan terhadap lokasi studi, instansi/dinas terkait di pusat dan daerah, koperasi dan asosiasi masyarakat petani garam, pengusaha sebagai produsen dan konsumen garam, serta stakeholder lainnya (seperti pedagang pengumpul, pedagang perantara, pengusaha transportasi, dsb).

5. Analisis pengembangan usaha dan peran kelembagaan petani garam dengan melakukan analisis kuantitatif (analisis SWOT) dan analisis kualitatif.

6. Workshop/Forum diskusi (PRA/LFA) dalam rangka pengelolaan dan pengembangan kelembagaan petani garam. Workshop dilakukan dalam bentuk forum diskusi yang dipandu oleh moderator, pada forum ini dibahas apa yang diinginkan para peserta, bagaimana mencapainya, rencana aksi, program dijalankan secara berkelanjutan (sustainable). Sejumlah pemegang kepentingan harus hadir atau diwakili pada forum ini, yaitu para petani garam, pengurus/manajer koperasi, Dekopin/Dekopinda, Pemerintah Daerah, Dinas- Dinas Pemerintahan terkait, Perguruan Tinggi setempat, LSM promotor lembaga swadaya Forum diskusi bisa dilakukan secara berjenjang, disesuaikan dengan batasan waktu dan biaya.

7. Implementasi rencana aksi yang telah dihasilkan dari Workshop yang telah dilakukan, dalam rangka menguatkan lembaga-lembaga koperasi khususnya petani garam sehingga dapat meningkatkan peran serta/partisipasi masyarakat perdesaan dalam pemberdayaan ekonomi lokal, serta melakukan sinergitas program/kegiatan dalam upaya peningkatan kapasitas kelembagaan koperasi masyarakat petani garam, yang pada pelaksanaannya dilakukan monitoring dan evaluasi sebagai umpan balik untuk didapatkan 
suatu rumusan kebijakan tentang penguatan kelembagaan koperasi di daerah tertinggal.

4.3. Tahap Pelaporan

Pada tahap ini para ahli dan asisten harus melaporkan hasil kegiatanya dan memberikan kontribusi kepada hasil studi yang menyeluruh sesuai dengan keahliannya. Hasil studi diharapkan memberikan landasan dan masukan dalam perumusan kebijakan pemerintah dalam menangani dan menanggulangi permasalahan serta mengembangkan potensi daerah tertinggal. 